\title{
Genetic diversity and differentiation of populations of Chlorops oryzae (Diptera, Chloropidae)
}

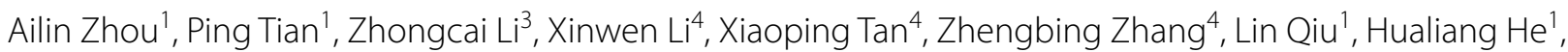 \\ Wenbing Ding ${ }^{1,2}$ and Youzhi Li ${ }^{1,2^{*}}$ (D)
}

\begin{abstract}
Background: Chlorops oryzae is an important pest of rice crops. There have been frequent outbreaks of this pest in recent years and it has become the main rice pest in some regions. To elucidate the molecular mechanism of frequent C. oryzae outbreaks, we estimated the genetic diversity and genetic differentiation of 20 geographical populations based on a dataset of ISSR markers and $\mathrm{COI}$ sequences.

Results: ISSR data revealed a high level of genetic diversity among the 20 populations as measured by Shannon's information index ( () , Nei's gene diversity $(H)$, and the percentage of polymorphic bands (PPB). The mean coefficient of gene differentiation (Gst) was 0.0997, which indicates that only $9.97 \%$ genetic variation is between populations. The estimated gene flow (Nm) value was 4.5165, indicating a high level of gene flow and low, or medium, genetic differentiation among some populations. The results of a Mantel test revealed no significant correlation between genetic and geographic distance among populations, which means there is no evidence of significant genetic isolation by distance. An UPGMA (unweighted pair-group method with arithmetic averages) dendrogram based on genetic identity, did not indicate any major geographic structure for the 20 populations examined. mtDNA COI data indicates low nucleotide (0.0007) and haplotype diversity (0.36) in all populations. Fst values suggest that the 20 populations have low, or medium, levels of genetic differentiation. And the topology of a Neighbor-Joining tree suggests that there are no independent groups among the populations examined.
\end{abstract}

Conclusions: Our results suggest that C. oryzae populations have high genetic diversity at the species level. There is evidence of frequent gene flow and low, or medium, levels of genetic differentiation among some populations. There is no significant correlation between genetic and geographic distance among C. oryzae populations, and therefore no significant isolation by distance. All results are consistent with frequent gene exchange between populations, which could increase the genetic diversity, and hence, adaptability of $C$. oryzae, thereby promoting frequent outbreaks of this pest. Such knowledge may provide a scientific basis for predicting future outbreaks.

Keywords: Chlorops oryzae, Mitochondrial DNA, ISSR, Genetic diversity, Genetic differentiation

*Correspondence: liyouzhi@hunau.edu.cn

${ }^{1}$ Hunan Provincial Key Laboratory for Biology and Control of Plant

Diseases and Insect Pests, College of Plant Protection, Hunan Agricultural

University, Changsha 410128, China

Full list of author information is available at the end of the article

\section{Background}

Chlorops oryzae (Diptera, Chloropidae) is an important pest of paddy rice plants, which inflicts significant economic damage to rice crops throughout Asia. However, the dispersal ability, potential for long-distance dispersal, pattern of migration, ecological amplitude, and population size of C. oryzae are still uncertain. Most

(c) The Author(s) 2020. This article is licensed under a Creative Commons Attribution 4.0 International License, which permits use, sharing, adaptation, distribution and reproduction in any medium or format, as long as you give appropriate credit to the original author(s) and the source, provide a link to the Creative Commons licence, and indicate if changes were made. The images or other third party material in this article are included in the article's Creative Commons licence, unless indicated otherwise in a credit line to the material. If material is not included in the article's Creative Commons licence and your intended use is not permitted by statutory regulation or exceeds the permitted use, you will need to obtain permission directly from the copyright holder. To view a copy of this licence, visit http://creativecommons.org/licenses/by/4.0/. The Creative Commons Public Domain Dedication waiver (http://creativecommons.org/publicdomain/zero/1.0/) applies to the data made available in this article, unless otherwise stated in a credit line to the data. 
research on this species has focused on the physiology and ecology [1-3], and its genetics is relatively unstudied [4].

Frequent $C$. oryzae outbreaks in recent years have caused the species to become a major pest in some regions. The propensity for outbreaks may itself play an important role in homogenizing genetic variation and intensifying gene flow between pest populations [5, 6]. We hypothesized that frequent gene flow between populations enhances the species' overall adaptability, promoting the frequent outbreaks that occur today. In other words, the frequent outbreaks of $C$. oryzae are associated with the species' genetic diversity, population demography and high rate of gene flow between populations.

To test this hypothesis, we evaluated the genetic structure of different geographic populations of $C$. oryzae and the level of gene flow between them. We quantified the genetic diversity and degrees of genetic differentiation of 20 different geographical populations, which may provide a scientific basis for predicting future outbreaks.

We used two effective and promising DNA markers, mitochondrial DNA (mtDNA) and inter-simple sequence repeat (ISSR), to examine between-population differences. Studies of genetic variation between pest populations can not only provide information on their population structure in different geographical regions, but also deduce the demographic history of this species [7-9]. Yi et al. used microsatellite and mtDNA loci to investigate the genetic divergence and dispersal ability of Bactrocera dorsalis (Hendel) on six offshore islands in South China, which results indicated that these populations have high genetic diversity, frequent gene flow and low, or medium, levels of genetic differentiation. Thus, the geographic isolation of the six islands is no barrier to the dispersal of $B$. dorsalis [10]. Research on the genetic diversity and population structure of Leucinodes orbonalis collected from a variety of agro-climatic conditions found almost no genetic diversity and no significant genetic variation among the mitochondrial gene Cytochrome Oxidase I (COI) gene sequences of the populations examined. However, a few genetically distinct populations were associated with some specific habitat requirements [11]. Similarly, genetic differentiation in ISSR markers and the COI gene among Iranian populations of Hishimonus phycitis may have been induced by geographical and ecological isolation and may have an impact on the vectoring capability of this insect [12].

Our results not only provide information on the genetic structure and phylogeography research of C. oryzae, but also provide a potential scientific basis for monitoring and controlling this pest.

\section{Results}

\section{COI gene analysis}

\section{Genetic diversity and differentiation}

In total, 432 individuals collected from different locations were used to amplify $684 \mathrm{bp}$ of the COI gene sequence, which defined 47 haplotypes. All 47 haplotypes had 43 variable sites, including 26 singleton variable sites and 17 parsimony informative sites. The mean total nucleotide frequencies of $\mathrm{A}, \mathrm{T}, \mathrm{C}$ and $\mathrm{G}$ in the nucleotide sequences from the 20 different populations were $29.98 \%, 36.56 \%, 16.95 \%$ and $16.51 \%$, respectively, which shows an obvious AT bias (66.54\%). The transition/transversion rate ratio was observed to be higher with purines (36.158) than pyrimidines (19.381). The overall transition/transversion bias was 12.022 .

Genetic diversity parameters of the 20 populations and the results of neutrality tests are shown in Table 1 . Haplotype diversity $(H d)$ for each population ranged from 0 to 0.71739 and the average number of differences $(k)$ ranged from 0 to 1.35145 . Nucleotide diversity $(\Pi)$ for each population ranged from 0 to 0.00198 . Tajima's $D$ and Fu's $F$ s test of neutrality of 19 populations showed a negative value. When all samples were calculated as one population, Tajima's $D$ and Fu's $F s$ values were negative and $1 \%$ significant, which is strong evidence of population expansion.

Based on our sequence database, inter- and intraspecific genetic distances of $C$. oryzae populations were $0.00012-0.00184$ and $0-0.00198$ (Table 2) respectively, which indicates no significant genetic differentiation. The Fst values between populations ranged from -0.0595 to 0.1174 (Table 3), indicating that inter-population differences are relatively low. AMOVA results suggest that $97.28 \%$ of all genetic variation is within, and only $2.72 \%$ between, populations (Table 4 ).

\section{Haplotype network and population tree}

Evolutionary relationships among the haplotypes were depicted using the median-joining network method (Fig. 1). Among the 47 haplotypes, $\mathrm{H} 1$ was the most frequent haplotype, which occupied a central position of the network and was diversified by 46 haplotypes. Especially, H23 and H45 can be derived from two different haplotypes with just one mutational step, respectively. The topology of the $C$. oryzae population NeighborJoining tree suggested that there were no independent groups in all populations (Fig. 2). It is worth mentioning that NX population is most distant on the haplotype network and population tree, however, there is no certain landscape features around the NX location. The reason for preventing emigration of individuals is still unknown. 
Table 1 Genetic diversity of 20 C. oryzae populations

\begin{tabular}{|c|c|c|c|c|c|c|c|c|c|}
\hline populations & $n$ & $h$ & $\mathrm{Hd}$ & $\mathrm{K}$ & $\mathrm{Pi}$ & Tajima's D & P-value & Fu's Fs & P-value \\
\hline TY & 24 & 4 & 0.23913 & 0.25000 & 0.00037 & -1.73253 & $0.10>P>0.05$ & -3.021 & 0.039 \\
\hline ZZ & 24 & 3 & 0.16304 & 0.16667 & 0.00024 & -1.51469 & $>0.10$ & -2.078 & 0.094 \\
\hline LS & 24 & 4 & 0.23913 & 0.25000 & 0.00037 & -1.73253 & $0.10 .>P>0.05$ & -3.021 & 0.039 \\
\hline YS & 24 & 3 & 0.16304 & 0.25000 & 0.00037 & -1.73253 & $0.10>P>0.05$ & -1.355 & 0.159 \\
\hline XT & 24 & 3 & 0.23551 & 0.24275 & 0.00035 & -1.20229 & $>0.10$ & -1.407 & 0.153 \\
\hline HS & 24 & 3 & 0.23551 & 0.24275 & 0.00035 & -1.20229 & $>0.10$ & -1.407 & 0.153 \\
\hline $\mathrm{HD}$ & 16 & 5 & 0.60833 & 1.07500 & 0.00157 & -1.38795 & $>0.10$ & -1.243 & 0.145 \\
\hline$J S$ & 16 & 4 & 0.35000 & 0.37500 & 0.00055 & -1.69654 & $0.10>P>0.05$ & -2.449 & 0.065 \\
\hline SM & 24 & 5 & 0.31159 & 0.33333 & 0.00049 & -1.88381 & $<0.05$ & -3.974 & 0.016 \\
\hline DC & 24 & 6 & 0.49638 & 0.64493 & 0.00094 & -1.81040 & $<0.05$ & -3.383 & 0.026 \\
\hline$X X$ & 24 & 8 & 0.56159 & 0.65942 & 0.00096 & -2.02600 & $<0.05$ & -6.535 & 0.001 \\
\hline$Y L$ & 8 & 1 & 0 & 0 & 0 & $\mathrm{~N}$ & $\mathrm{~N}$ & $\mathrm{~N}$ & N \\
\hline YX & 24 & 3 & 0.30072 & 0.31159 & 0.00046 & -0.91964 & $>0.10$ & -0.960 & 0.200 \\
\hline SS & 24 & 4 & 0.23913 & 0.33333 & 0.00049 & -1.88381 & $<0.05$ & -2.331 & 0.070 \\
\hline LL & 24 & 7 & 0.71739 & 1.15942 & 0.00170 & -1.19233 & $>0.10$ & -2.620 & 0.047 \\
\hline TJ & 24 & 4 & 0.23913 & 0.25000 & 0.00037 & -1.73253 & $0.10>P>0.05$ & -3.021 & 0.039 \\
\hline LH & 24 & 6 & 0.38043 & 0.41667 & 0.00061 & -1.99611 & $<0.05$ & -4.976 & 0.006 \\
\hline $\mathrm{GZ}$ & 8 & 2 & 0.25000 & 0.25000 & 0.00037 & -1.05482 & $>0.10$ & -0.182 & 0.354 \\
\hline Z」 & 24 & 5 & 0.37681 & 0.48551 & 0.00071 & -1.49528 & $>0.10$ & -2.842 & 0.043 \\
\hline NX & 24 & 9 & 0.66304 & 1.35145 & 0.00198 & -1.98791 & $<0.05$ & -4.496 & 0.008 \\
\hline Total & 432 & 47 & 0.36000 & 0.48000 & 0.00070 & -2.56478 & $<0.001$ & -100.982 & 0.000 \\
\hline
\end{tabular}

$\mathrm{n}$ : Number of individual, h: Number of haplotype, Hd: Haplotype diversity, K: Average number of differences, Pi: Nucleotide diversity

\section{ISSR-PCR analysis \\ Genetic diversity}

197 fragments were generated from the 9 primers, ranging in size from 250 to $2000 \mathrm{bp}$, and with an average of 21.89 fragments per primer. The percentage of polymorphic bands was 100\% showing high genetic diversity at the species level. Among the 20 populations, PPB values ranged from $89.85 \%$ to $99.49 \%$. The $\mathrm{Na}$ and $\mathrm{Ne}$ were $2.0000 \pm 0.0000(1.8985 \pm 0.3028$ to $1.9949 \pm 0.0712$ among populations) and $1.6460 \pm 0.2373(1.4992 \pm 0.3270$ to $1.6908 \pm 0.2784$ among populations), respectively. The $H$ and $I$ were $0.3785 \pm 0.0984(0.2992 \pm 0.1588$ to $0.3893 \pm 0.1196)$ and $0.5609 \pm 0.1151 \quad(0.4547 \pm 0.2091$ to $0.5692 \pm 0.1457)$, respectively, within all samples (Table 5).

\section{Genetic differentiation}

The Gst was 0.0997, which indicates that $90.03 \%$ genetic variation is within populations and only $9.97 \%$ between populations. The estimated $\mathrm{Nm}$ value was 4.5165 (Table 6). These results suggest that genetic differentiation among populations of $C$. oryzae is impeded by high gene flow. Table 7 lists the genetic identity (above diagonal) and genetic distance (below diagonal) among populations.
The relationship between genetic and geographic distance was shown in Fig. 3. A Mantel test revealed no significant correlation between genetic and geographic distance $(\mathrm{r}=0.54675, \mathrm{p}=0.9992)$ among $C$. oryzae populations, and there was therefore no evidence of significant isolation by distance.

An UPGMA dendrogram constructed based on genetic identity (Fig. 4) grouped the 20 populations into two major clusters. The dendrogram did not reveal any major geographic structure for these populations.

\section{Discussion}

The rapid development of molecular techniques has made it possible to directly measure genetic differentiation and genetic diversity among populations [13]. The faster mutation rate and relatively conserved sequence of the mtDNA COI gene is ideally suited to species identification via DNA barcoding [14]. Analysis of mtCOI gene variation is regarded as an important and reliable tool for defining cryptic species [15], evaluating biodiversity [16], identifying samples [17], and distinguishing closely related species [18].

Various surveys have demonstrated the reliability of ISSR markers, which can generate more polymorphisms than either RAPD or RFLP, [19]. For example, Dioscorea hispida were grouped into 10 vital groups 


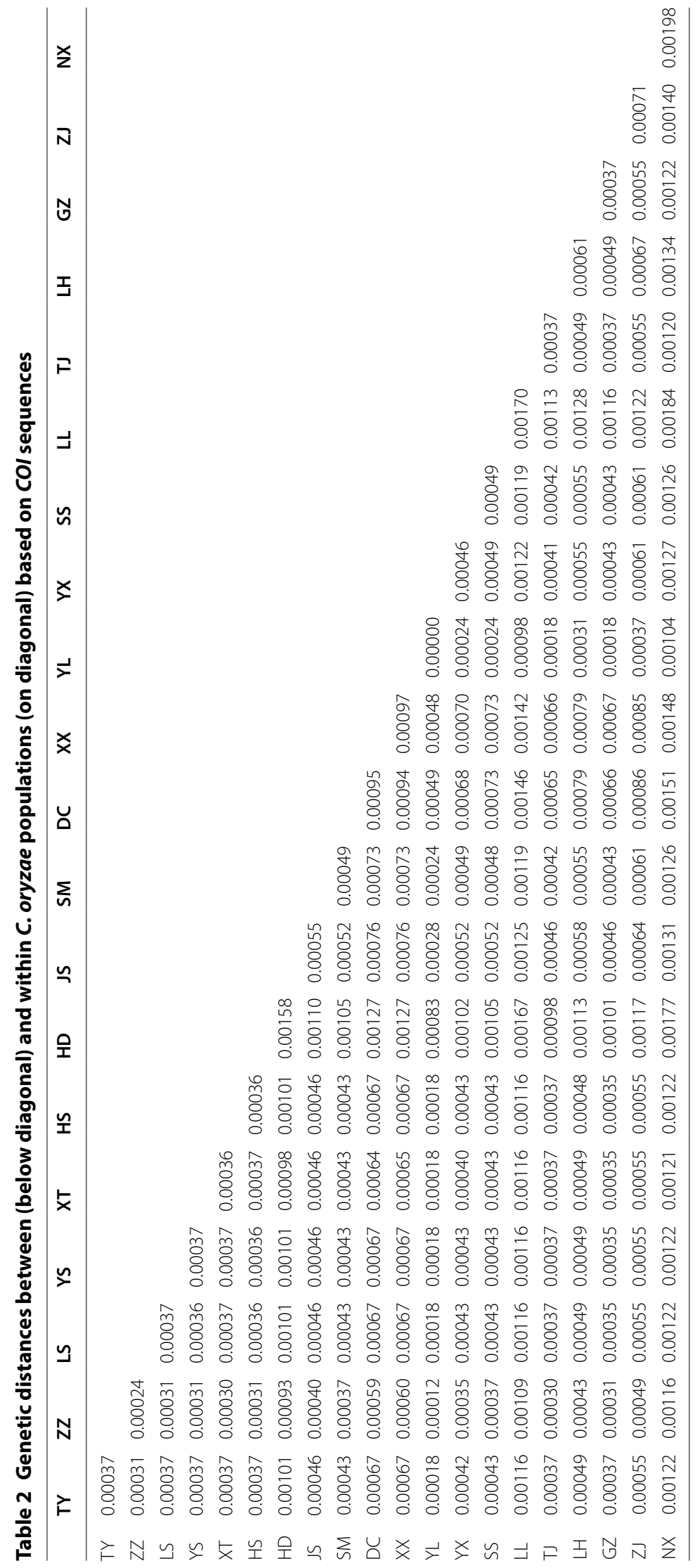




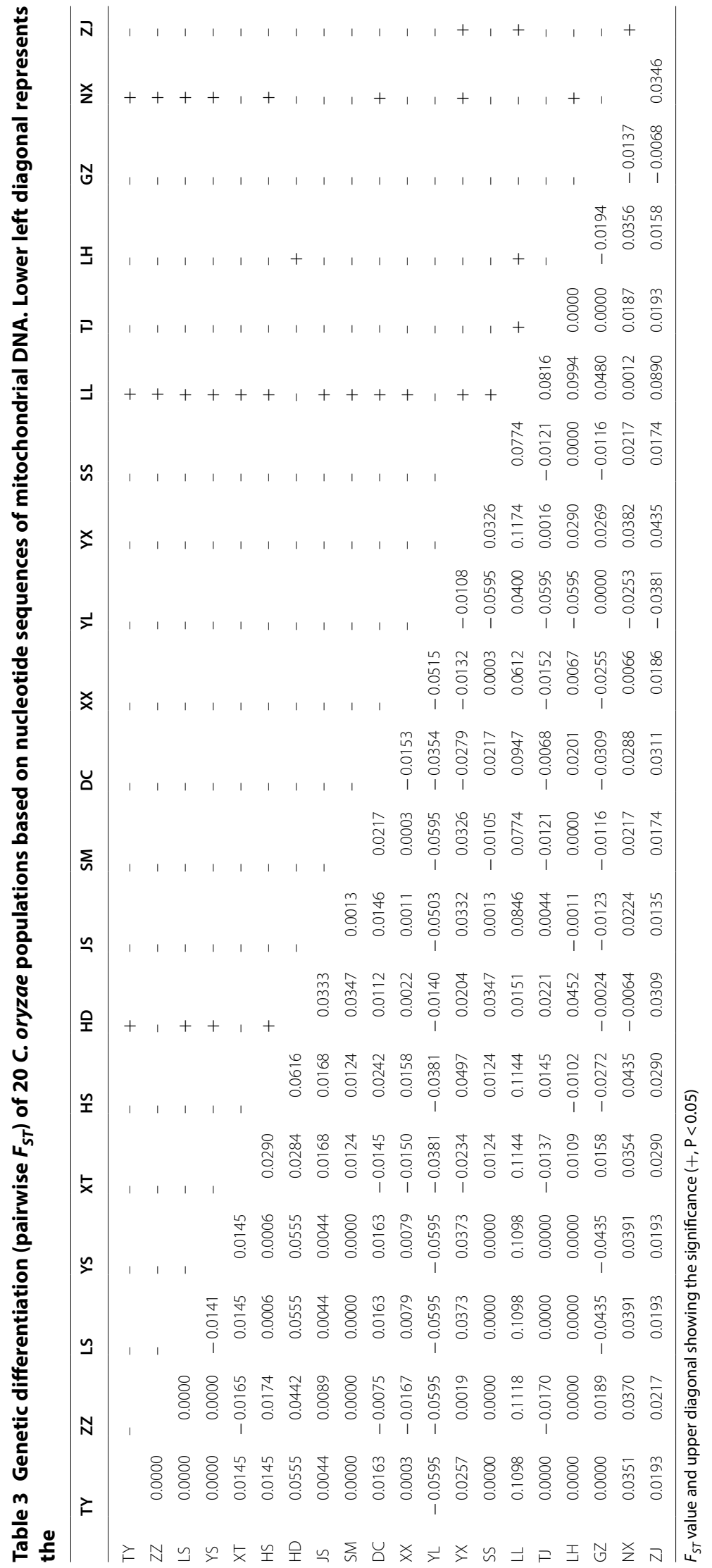


Table 4 AMOVA analysis of mtDNA COI gene sequences in $20 \mathrm{C}$. oryzae populations

\begin{tabular}{lcccc}
\hline Source of variation & df & Sum of squares & Variance components & $\begin{array}{c}\text { Percentage } \\
\text { of variation }\end{array}$ \\
\hline Among populations & 19 & 7.116 & $0.00654 \mathrm{Va}$ & 2.72 \\
Within populations & 412 & 96.250 & $0.23362 \mathrm{Vb}$ & 97.28 \\
Total & 431 & 103.366 & 0.24016 & 100 \\
\hline
\end{tabular}

Fst $=0.02724(P=0.000)$

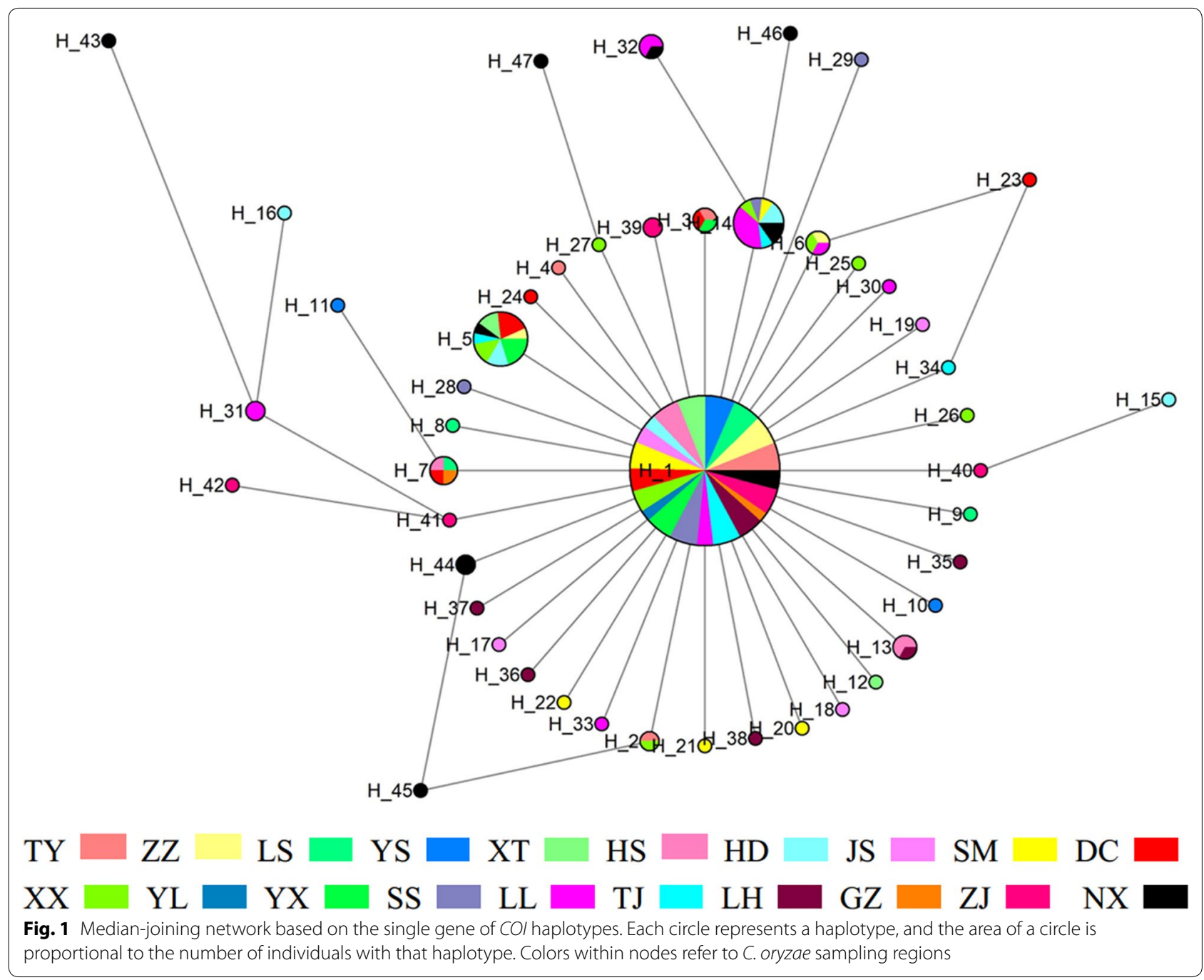

based on information that provided by ISSR markers, proving the existence of significant variation among germplasm specimens. D. hispida shows a high level of genetic diversity among accessions, which suggests that ISSR markers have been very effective in detecting polymorphism in this species [20]. ISSR primers have been used to determine the potential for the diversification of cassava crops in Angola, revealing genetic diversity within populations and genetic information sharing among the three main taxa [21]. The ISSR molecular marker technique has also been used to distinguish between citrus rootstock species, and to reveal the broad genetic base and high genetic variability among these [22].

\section{Genetic diversity}

Genetic diversity, also known as gene diversity, is the foundation of biodiversity that guarantees the evolution 


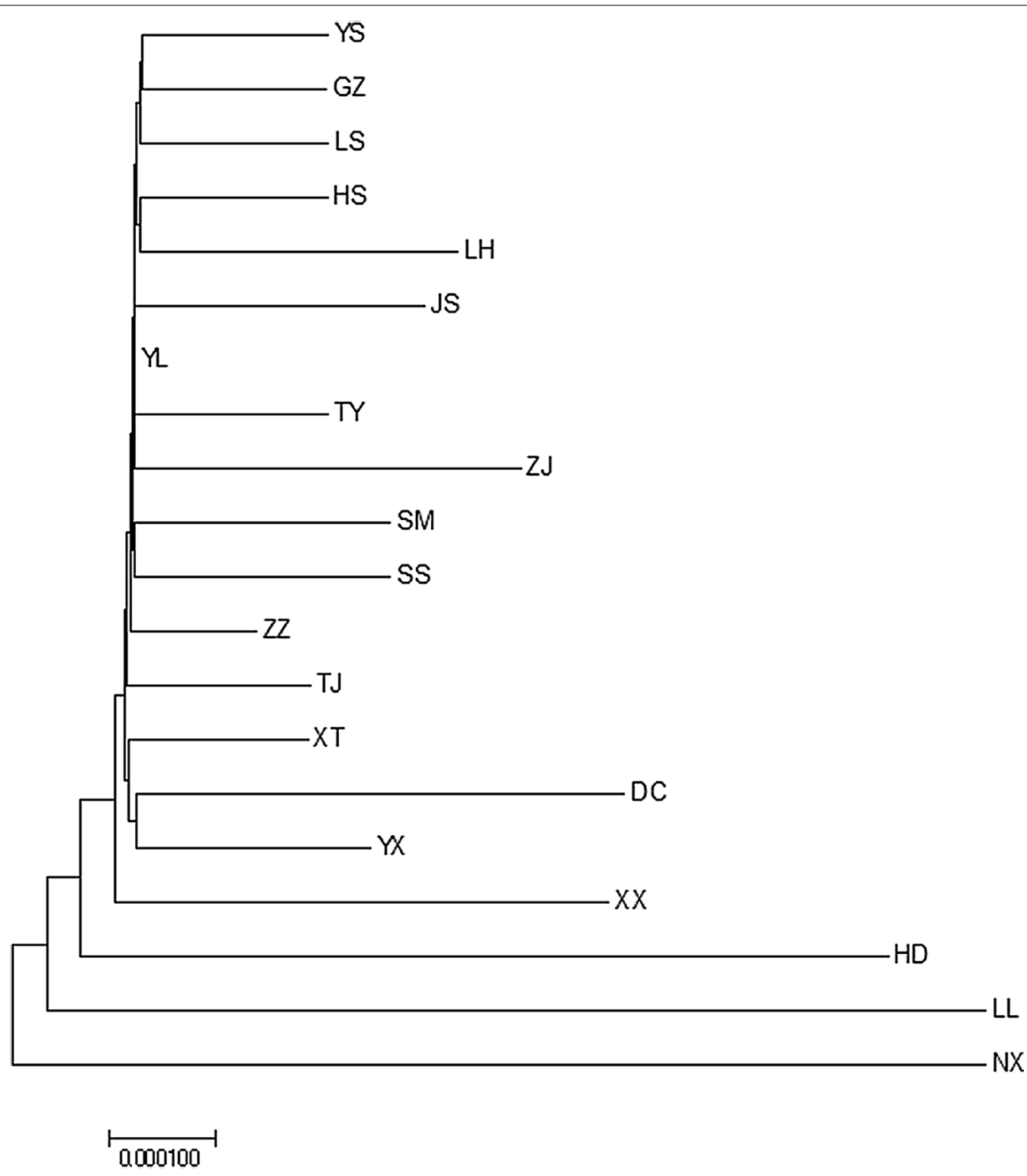

Fig. 2 Neighbor-joining tree (model Kimura-2 parameter) of the phylogenetic relationships among 20 C. oryzae populations based on COI gene variation (1000 bootstrap replicates)

of species. The percentage of polymorphism, haplotype diversity and nucleotide diversity are used to evaluate population genetic diversity [10]. High levels of genetic diversity are indicative of the strong viability and adaptability of populations [23]. Results from this study indicate that the genetic diversity of $C$. oryzae was high between populations that were sampled. This may increase fitness in populations to changing conditions. Crawford and Whitney [24] also showed that genetic diversity increases the ability of species to colonize on a short-term ecological timescale by increasing the possibility of population survival, growth and reproduction under novel environments. Episyrphus balteatus and Sphaerophoria scripta European populations successfully adapt to changing environmental conditions and have great colonization abilities due to the high genetic diversity [25]. The Tajima's $D$ and Fu's $F s$ test of neutrality values for 19 populations were negative. When all samples were calculated as one population, Tajima's $D$ and Fu's $F s$ values were negative and $1 \%$ significant, strongly indicating population expansion. This result is consistent with the idea that the negative Tajima's $D$ and Fu's $F$ s test values demonstrated demographic expansion has occurred in these populations. 
Table 5 Genetic variation among C. oryzae populations

\begin{tabular}{|c|c|c|c|c|c|c|}
\hline Population & $\begin{array}{l}\text { Number } \\
\text { of polymorphic } \\
\text { bands }\end{array}$ & PPB (\%) & $\mathrm{Na}$ & $\mathrm{Ne}$ & $H$ & $I$ \\
\hline TY & 189 & 95.94 & $1.9594 \pm 0.1979$ & $1.5564 \pm 0.2981$ & $0.3307 \pm 0.1428$ & $0.4970 \pm 0.1848$ \\
\hline ZZ & 194 & 98.48 & $1.9848 \pm 0.1228$ & $1.5755 \pm 0.2915$ & $0.3410 \pm 0.1342$ & $0.5119 \pm 0.1683$ \\
\hline LS & 192 & 97.46 & $1.9746 \pm 0.1577$ & $1.6440 \pm 0.2820$ & $0.3704 \pm 0.1275$ & $0.5460 \pm 0.1612$ \\
\hline YS & 190 & 96.45 & $1.9645 \pm 0.1856$ & $1.5740 \pm 0.2886$ & $0.3404 \pm 0.1355$ & $0.5101 \pm 0.1736$ \\
\hline XT & 189 & 95.94 & $1.9594 \pm 0.1979$ & $1.6300 \pm 0.3049$ & $0.3604 \pm 0.1431$ & $0.5309 \pm 0.1855$ \\
\hline HS & 194 & 98.48 & $1.9848 \pm 0.1228$ & $1.6908 \pm 0.2784$ & $0.3893 \pm 0.1196$ & $0.5692 \pm 0.1457$ \\
\hline $\mathrm{HD}$ & 191 & 96.95 & $1.9695 \pm 0.1723$ & $1.5777 \pm 0.2993$ & $0.3403 \pm 0.1395$ & $0.5095 \pm 0.1773$ \\
\hline JS & 187 & 94.92 & $1.9492 \pm 0.2201$ & $1.5680 \pm 0.3006$ & $0.3360 \pm 0.1403$ & $0.5036 \pm 0.1817$ \\
\hline SM & 194 & 98.48 & $1.9848 \pm 0.1228$ & $1.6039 \pm 0.2831$ & $0.3545 \pm 0.1278$ & $0.5287 \pm 0.1584$ \\
\hline DC & 196 & 99.49 & $1.9949 \pm 0.0712$ & $1.5609 \pm 0.2835$ & $0.3367 \pm 0.1272$ & $0.5091 \pm 0.1556$ \\
\hline$X X$ & 195 & 98.98 & $1.9898 \pm 0.1005$ & $1.5200 \pm 0.2769$ & $0.3193 \pm 0.1283$ & $0.4881 \pm 0.1596$ \\
\hline$Y L$ & 177 & 89.85 & $1.8985 \pm 0.3028$ & $1.5646 \pm 0.3245$ & $0.3289 \pm 0.1578$ & $0.4893 \pm 0.2113$ \\
\hline YX & 192 & 97.46 & $1.9746 \pm 0.1577$ & $1.5377 \pm 0.2914$ & $0.3243 \pm 0.1370$ & $0.4916 \pm 0.1737$ \\
\hline SS & 187 & 94.92 & $1.9492 \pm 0.2201$ & $1.5917 \pm 0.3165$ & $0.3426 \pm 0.1501$ & $0.5087 \pm 0.1955$ \\
\hline LL & 192 & 97.46 & $1.9746 \pm 0.1577$ & $1.6025 \pm 0.2834$ & $0.3539 \pm 0.1281$ & $0.5275 \pm 0.1615$ \\
\hline TJ & 195 & 98.98 & $1.9898 \pm 0.1005$ & $1.5816 \pm 0.2890$ & $0.3443 \pm 0.1310$ & $0.5167 \pm 0.1621$ \\
\hline LH & 195 & 98.98 & $1.9898 \pm 0.1005$ & $1.5947 \pm 0.2691$ & $0.3536 \pm 0.1172$ & $0.5300 \pm 0.1420$ \\
\hline GZ & 180 & 91.37 & $1.9137 \pm 0.2815$ & $1.5762 \pm 0.3268$ & $0.3342 \pm 0.1551$ & $0.4969 \pm 0.2048$ \\
\hline ZJ & 185 & 93.91 & $1.9391 \pm 0.2398$ & $1.4992 \pm 0.3270$ & $0.2992 \pm 0.1588$ & $0.4547 \pm 0.2091$ \\
\hline NX & 190 & 96.45 & $1.9645 \pm 0.1856$ & $1.5801 \pm 0.2966$ & $0.3416 \pm 0.1393$ & $0.5106 \pm 0.1791$ \\
\hline Total & 197 & 100.00 & $2.0000 \pm 0.0000$ & $1.6460 \pm 0.2373$ & $0.3785 \pm 0.0984$ & $0.5609 \pm 0.1151$ \\
\hline
\end{tabular}

$P P B$ the percentage of polymorphic bands, $\mathrm{Na}$ Observed number of alleles, $\mathrm{Ne}$ effective number of alleles

$H=$ Nei's (1973) gene diversity, $I=$ Shannon's information index

Table 6 Population genetic differentiation coefficients and gene flow among $C$. oryzae populations

\begin{tabular}{lllll}
\hline & $\begin{array}{l}\text { Total } \\
\text { genetic } \\
\text { diversity } \\
(\boldsymbol{H} \boldsymbol{t})\end{array}$ & $\begin{array}{l}\text { Genetic } \\
\text { diversity } \\
\text { within } \\
\text { populations } \\
(\boldsymbol{H s})\end{array}$ & $\begin{array}{l}\text { Coefficient } \\
\text { of gene } \\
\text { differentiation } \\
(\mathbf{G s t})\end{array}$ & $\begin{array}{l}\text { Gene } \\
\text { flow } \\
(\mathbf{N m})\end{array}$ \\
\hline $\begin{array}{l}\text { Mean } \\
\begin{array}{c}\text { Standard } \\
\text { deviation }\end{array}\end{array}$ & 0.3799 & 0.3421 & 0.0997 & 4.5165 \\
\hline
\end{tabular}

\section{Genetic differentiation}

Fst values between $C$. oryzae populations ranged from -0.0595 to 0.1174 , and the Gst value was 0.0997 , both of which are indicative of low genetic differentiation between populations. This suggests frequent gene flow between populations, which may increase the species' adaptability to environmental change [26]. Moreover, gene flow can not only demonstrate the probable genetic differentiation and genetic infiltration among populations, but also reduce the genetic differences among populations [27]. In this research, the $N m$ value of $C$. oryzae was 4.5165 which indicates high gene flow and low, or medium, genetic differentiation among some populations. High gene flow may impede genetic differentiation in C. oryzae. Gene flow (or lack of gene flow) plays a crucial role in genetic differentiation, affects the overall adaption of entire species and adaptative divergence between populations [28]. It has been traditionally considered as a homogeneous force that limits adaptive differences [29, 30], and recent studies have shown that it can also promote adaptation to local environmental conditions [31, 32]. For example, moderate gene flow increases the adaptation capabilities of Rhagoletis cerasi populations (which occupy different habitates in fragmented landscapes) to local habitates, thus preventing them from becoming extinct due to genetic processes [33, 34].

An AMOVA based on Fst values indicates that most of the genetic variation was resulted from the difference within populations. Furthermore, a Mantel test indicates no significant correlation between genetic and geographic distance. This result is consistent with the findings of Yang et al. [35] who compared correlation of the symmetric matrix constituted by geographic and genetic distances to analyze the existence of isolation among populations of Odontotermes formosanus in different regions. These authors found no significant 


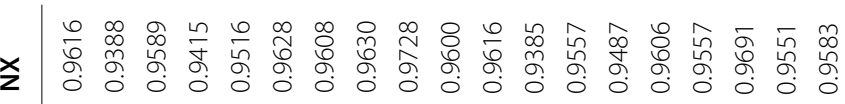

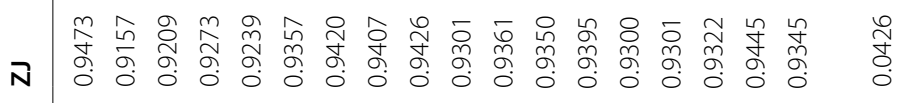

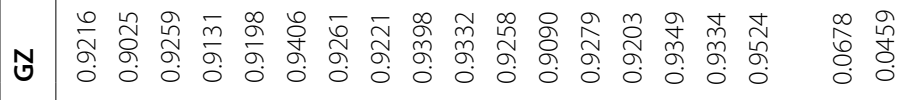

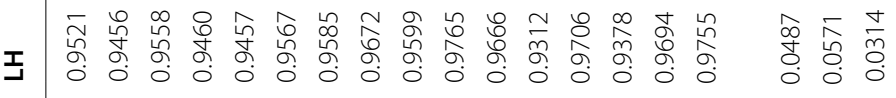

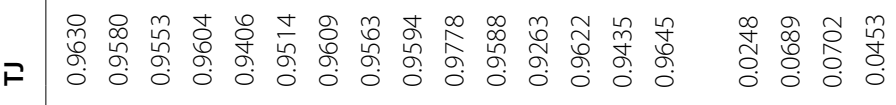

n.J

m

थ

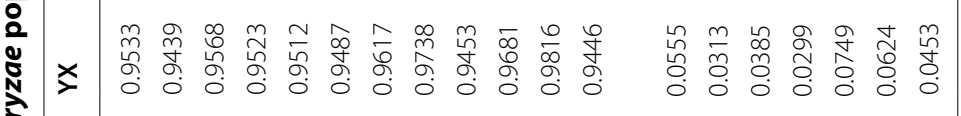

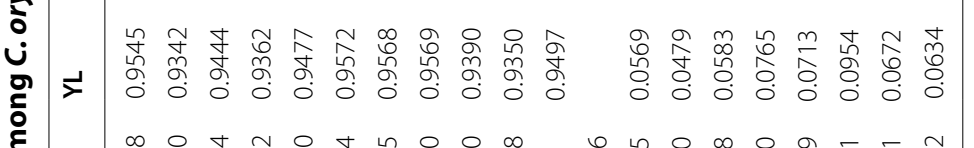

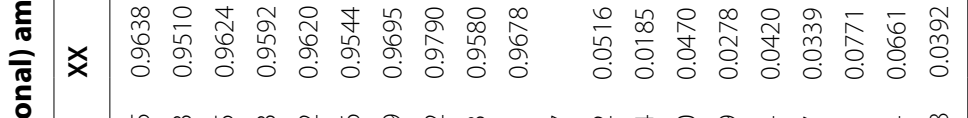

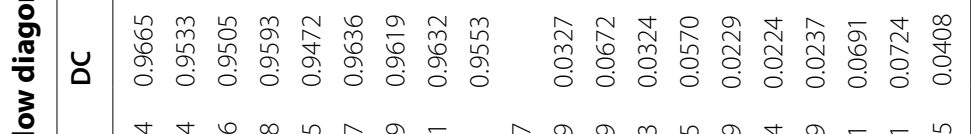

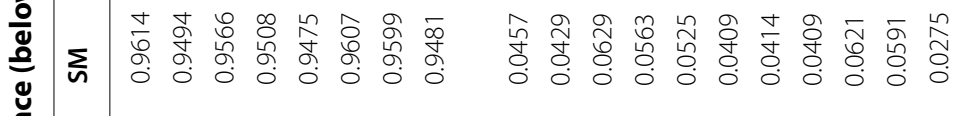

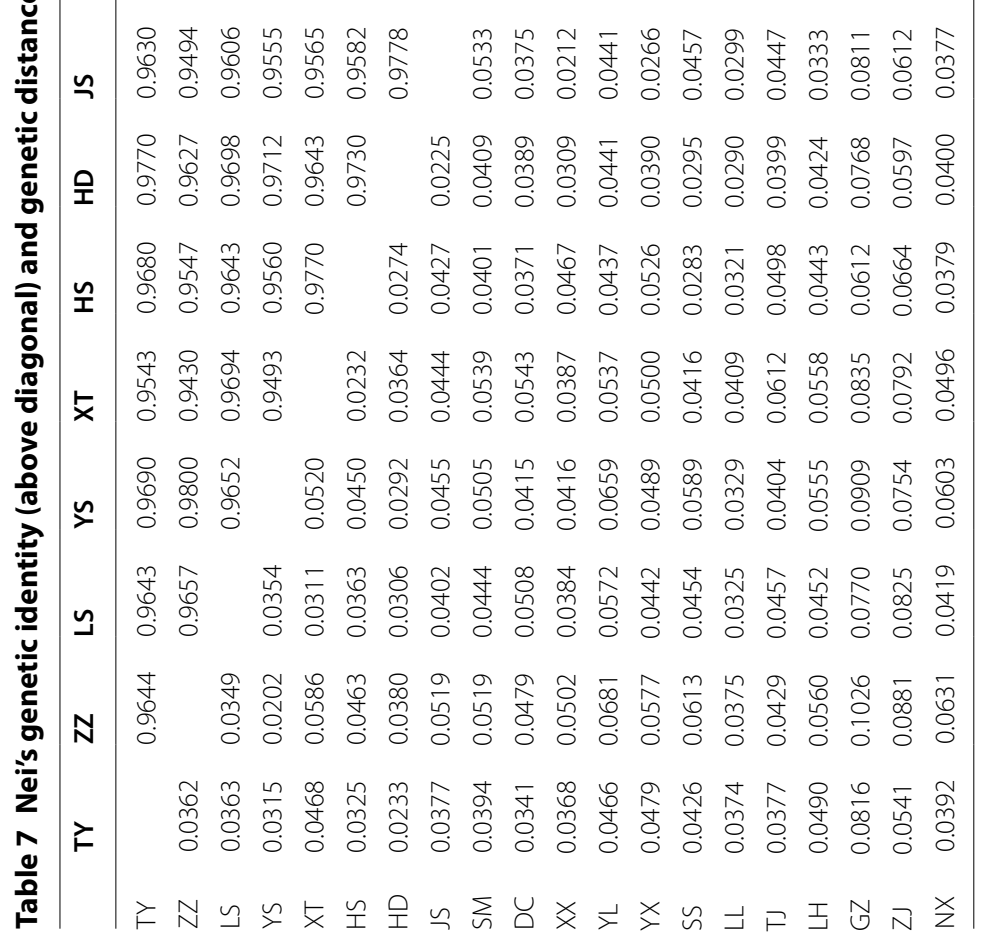




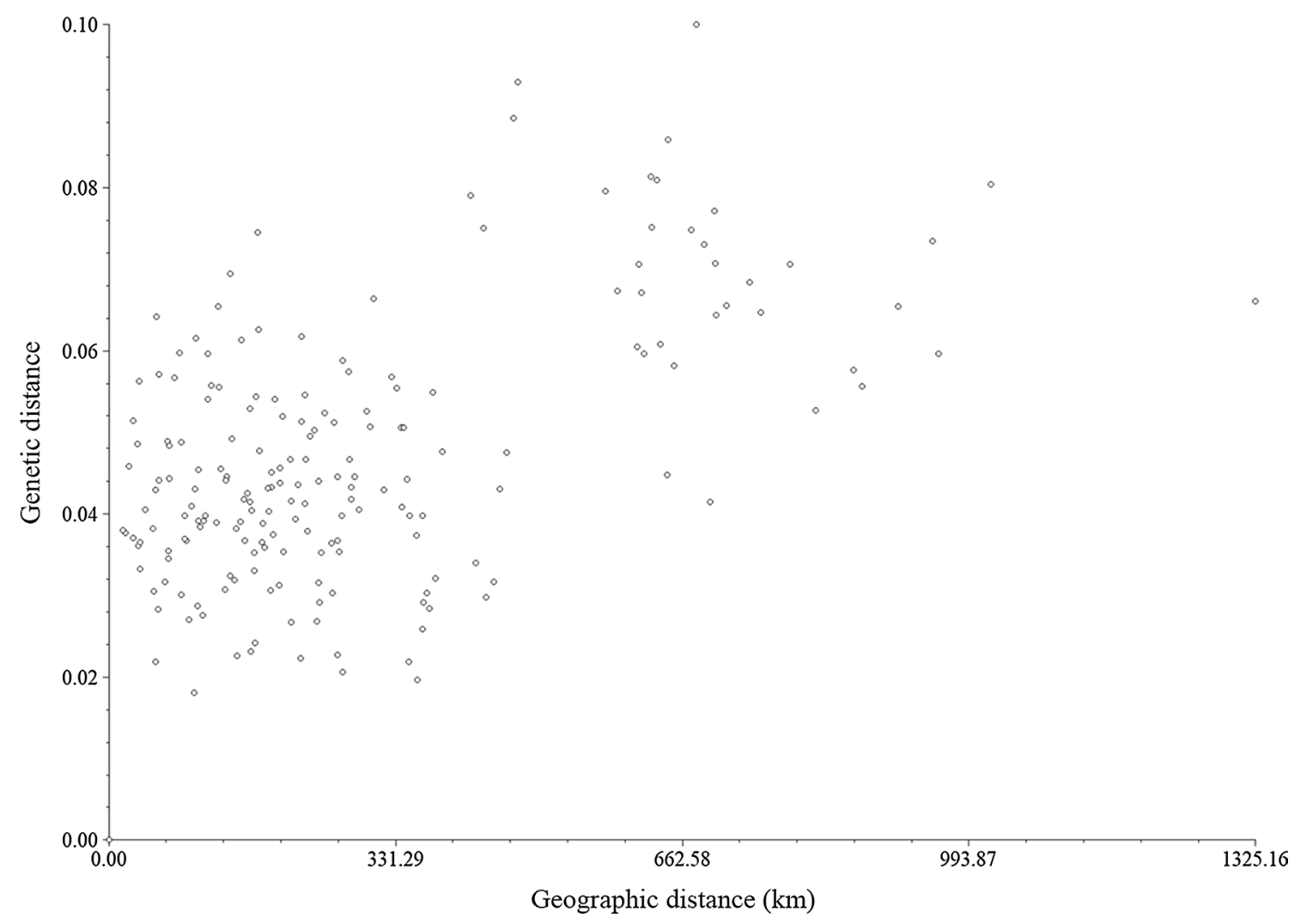

Fig. 3 Relationship between genetic distance and geographic distance of 20 C. oryzae populations

correlation between geographic distance and genetic distance and no significant isolation by distance. Overall, we found a high level of genetic diversity and a low degree of population differentiation among populations of C. oryzae, and the gene flow was unaffected by geographic distance. Similarly, geographic distance did not appear to affect gene flow between 10 geographically separated populations Oedaleus infernalis [36]. Fst and Gst values for these populations are low, and the gene flow is high, indicating a low level of genetic differentiation and high gene flow among populations [36]. The correlation between genetic and geographic distance was insignificant [36].

Our results provide important, new information on the genetic diversity and genetic differentiation of $C$. oryzae, and suggest that high gene flow between populations contributes to the now frequent outbreaks of this pest. However, further research on both additional geographical populations and different genetic markers are necessary before definitive conclusions can be reached. Furthermore, future work can focus on doing a more comprehensive ecological and behavioural research to understand the natural history of C. oryzae in greater detail.

\section{Conclusions}

This study showed that the now frequent outbreaks of C. oryzae may due to high gene flow between populations. We have found that these populations have high genetic diversity at the species level, whereas exhibited low genetic differentiation. High genetic diversity and frequent gene flow between populations may enhance the tolerance of populations to environmental variability and increase the adaptability to novel environmental pressures, leading to frequent outbreaks what had happened and what will happen in a large scale.

\section{Methods}

Sample collection and DNA extraction

400 specimens of $C$. oryzae were collected from different parts of Hunan province, China, and an additional 32 specimens from Zhejiang and Guizhou provinces (Fig. 5, Additional file 1: Table S1). Samples were soaked in $100 \%$ ethanol and stored at $-20^{\circ} \mathrm{C}$ until their genomic DNA (gDNA) was isolated. After removing the residual 


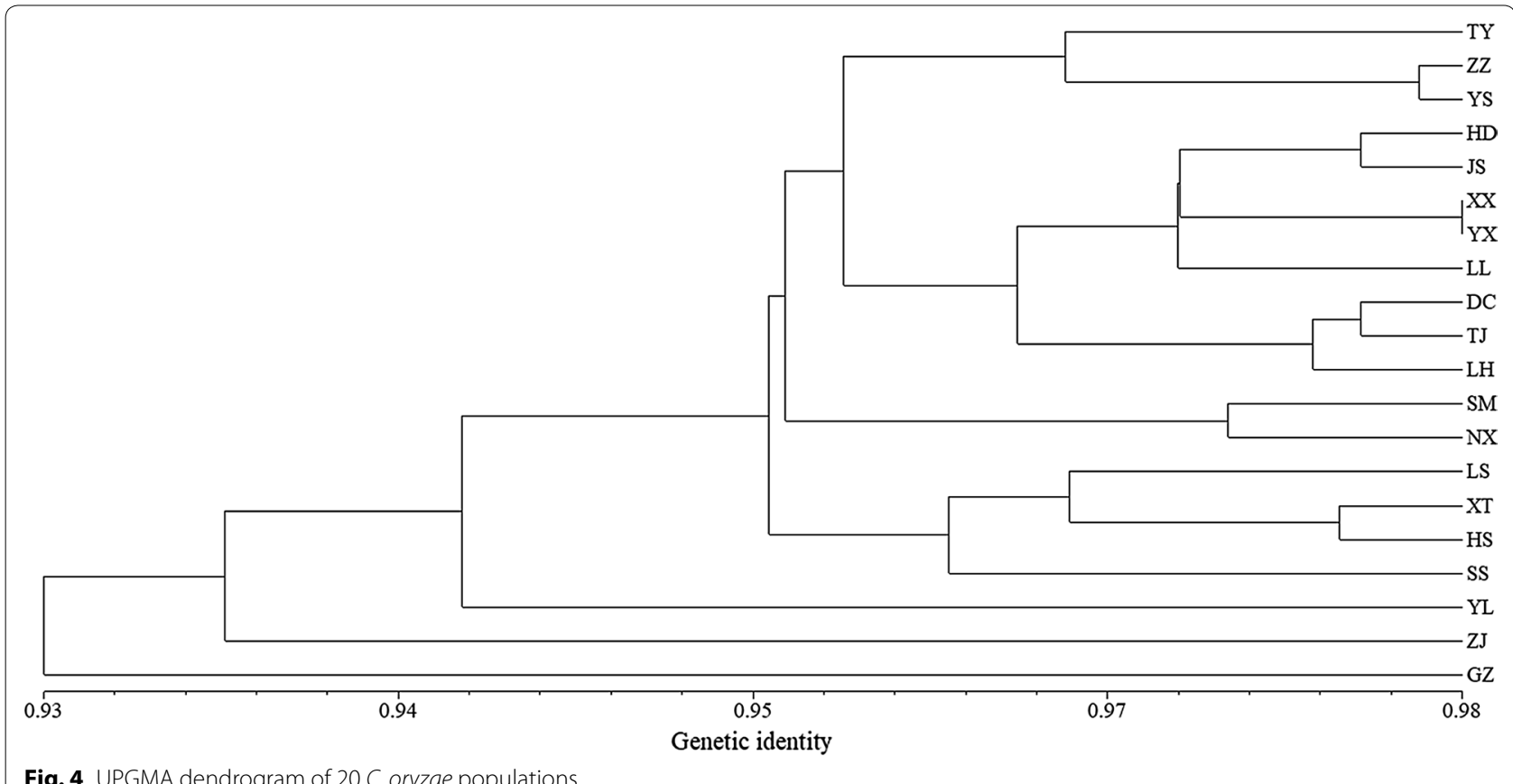

ethanol, DNA was extracted from each individual using an Ezup Column Animal Genomic DNA Extraction Kit as per the manufacturer's instructions (Sangon Biotech, Shanghai, China).

\section{COI PCR amplification and sequencing}

The COI was amplified with the COIF (5'-CTAGGT GCTCCAGATATAGCATTTC-3') and COIR (5'-GGC TAAAACAACTCCTGTTAATCC- $3^{\prime}$ ) primers from isolated DNA. PCR was performed in $20 \mu \mathrm{L}$ volumes comprised of $10 \mu \mathrm{L}$ PrimeSTAR Max DNA Polymerase (TaKaRa, Tokyo, Japan), $1 \mu \mathrm{L}$ of each primer (10 mmol/L), $1 \mu \mathrm{L}$ of template DNA solution $(70 \mathrm{ng} /$ $\mu \mathrm{L}$ ), and $7 \mu \mathrm{L}$ double distilled water. Amplifications were conducted as follows: 34 cycles of denaturation at $94{ }^{\circ} \mathrm{C}$ for $30 \mathrm{~s}$, annealing at $59^{\circ} \mathrm{C}$ for $30 \mathrm{~s}$, and extension at $72{ }^{\circ} \mathrm{C}$ for $1 \mathrm{~min}$. All the PCR products were checked by electrophoresis on a $1.2 \%$ agarose gel and bidirectional sequencing was completed by TSINGKE (Beijing, China).

\section{ISSR PCR amplification}

A total of sixteen primers from the University of British Columbia Biotechnology Laboratory Primer kit No.9 were tested for PCR and nine (Additional file 1: Table S2) that could produce reproducible, clear, polymorphic electrophoretic bands were chosen for further analysis. PCR was performed in $20 \mu \mathrm{L}$ volumes comprised of $10 \mu \mathrm{L}$ Premix $\operatorname{Taq}^{\mathrm{TM}}$ (Ex Taq $^{\mathrm{TM}}$ Version 2.0 plus dye) (TaKaRa,
Tokyo, Japan), $2 \mu \mathrm{L}$ of primer $(10 \mathrm{mmol} / \mathrm{L}), 1 \mu \mathrm{L}$ of template DNA solution $(70 \mathrm{ng} / \mu \mathrm{L})$, and $7 \mu \mathrm{L}$ double distilled water. Amplifications were carried out as follows: an initial denaturing at $94{ }^{\circ} \mathrm{C}$ for $3 \mathrm{~min}$, followed by 34 cycles of denaturing at $94{ }^{\circ} \mathrm{C}$ for $30 \mathrm{~s}$, annealing at an optimized temperature for $30 \mathrm{~s}$, and extension at $72{ }^{\circ} \mathrm{C}$ for $1 \mathrm{~min}$, with a final extension $7 \mathrm{~min}$ at $72{ }^{\circ} \mathrm{C}$. All PCR products were electrophoretically separated on $2 \%$ agarose.

\section{Data analysis}

\section{COI gene data analysis}

COI sequences were edited manually with BioEdit v.7.0.9 to produce consensus sequences of $685 \mathrm{bp}$ for each specimen [37]. All indices for sequence polymorphic sites, DNA polymorphism, genetic differentiation, neutrality tests [Tajima's $D$ [38] and Fu's Fs [39] ], and haplotype analyses were executed using DnaSp v.5.10 [40]. A haplotype network, which included haplotype frequencies, was calculated using Network v.4.6 [41]. Intra- and inter-specific genetic distances and transition/transversion ratios in each codon were computed based on COI gene sequences using MEGA v.7.0 [42]. A population phylogenetic tree based on genetic distances was constructed using the Neighbor-Joining tree model in MEGA v.7.0. Analysis of molecular variance (AMOVA) was performed with Arlequin software v.3.5.2 [43]. 


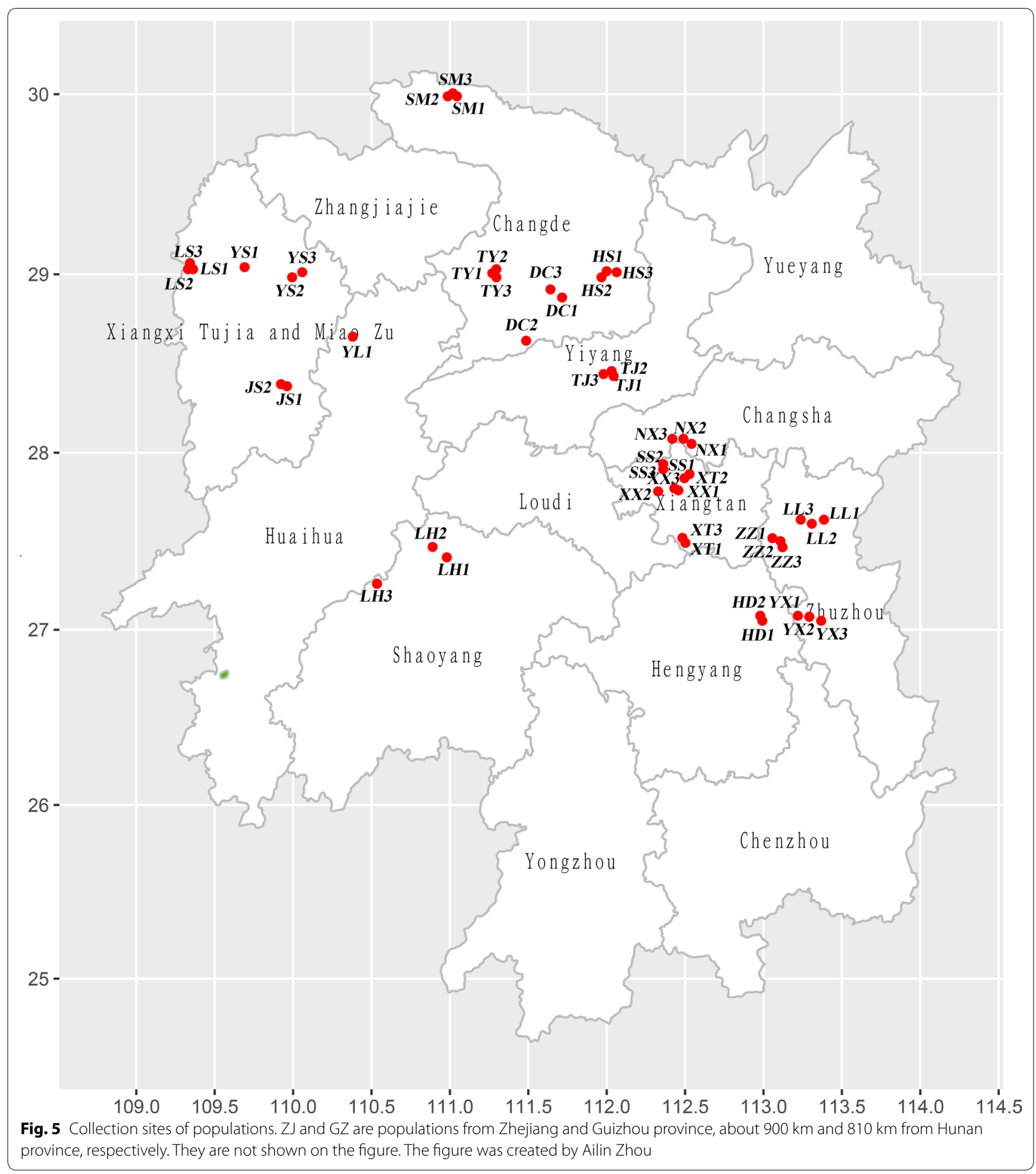

\section{ISSR data analysis}

Amplified ISSR fragments were scored as present (1) or absent (0) according to the molecular weight (bp) and the resulting matrix of binary values was used for further analyses. The observed number of alleles $(\mathrm{Na})$, effective number of alleles $(\mathrm{Ne})$, Nei's gene diversity $(H)$, Shannon's information index $(I)$, the percentage of polymorphic bands (PPB), total gene diversity $(H t)$, genetic diversity within populations $(H s)$, coefficient of gene differentiation (Gst), and Gene flow ( $\mathrm{Nm}$ ) were calculated using POPOGENE v.1.31 [44]. Cluster analysis was used to construct dendrograms using the UPGMA (unweighted pair-group 
method with arithmetic averages) in NTSYSpc v.2.1 [45]. To estimate the existence of isolation among 20 C. ory$z a e$ populations, the geographic distances between them were calculated using the google-maps-distance-calculator (www. daftlogic.com/projects-google-maps-distance-calculator. htm) (Additional file 1: Table S3). The correlation between geographic and genetic distances was further analyzed using the MXCOMP program and a Mantel test in NTSYSpc v.2.1.

\section{Supplementary information}

Supplementary information accompanies this paper at https://doi. org/10.1186/s12898-020-00293-8.

Additional file 1. Additional tables.

\section{Abbreviations}

mtDNA: Mitochondrial DNA; ISSR: Inter-simple sequence repeat; gDNA: Genomic DNA; COI: Mitochondrial gene Cytochrome Oxidase I; AMOVA: Analysis of molecular variance; Na: The observed number of alleles; Ne: Effective number of alleles; $H$ : Nei's gene diversity; l: Shannon's information index; PPB: The percentage of polymorphic bands; Ht:Total gene diversity; Hs: Genetic diversity within populations; Gst: Coefficient of gene differentiation; Nm: Gene flow; UPGMA: Unweighted pair-group method with arithmetic averages; $H d$ : Haplotype diversity; $k$ : The average number of differences; $\Pi$ : Nucleotide diversity.

\section{Acknowledgements}

We wish to thank Zhongcai Li, Xinwen Li, Xiaoping Tan and Zhengbing Zhang for their help in collecting the material in this study.

\section{Authors' contributions}

$\mathrm{AZ}$ and PT performed the experiments. ZL, $\mathrm{XL}, \mathrm{XT}, \mathrm{ZZ}, \mathrm{WD}$ and $\mathrm{YL}$ conceived and designed the experiments. $\mathrm{AZ}, \mathrm{LQ}$ and $\mathrm{HH}$ analyzed the data and wrote the manuscript. All authors read and approved the final manuscript.

\section{Funding}

This study was supported by Changsha City Science and Technology Bureau Key Projects, China (kc1701003).

Double first-class construction project of Hunan Agricultural University (SYL2019029)

\section{Availability of data and materials}

The authors declare that the data supporting the finding of this study are available in the article and its additional files.

\section{Ethic approval and consent to participate}

No permissions were required for sampling. There is no any regional/national legislature/law require ethical approval for sampling.

\section{Consent for publication}

Not applicable.

\section{Competing interests}

The authors declare that they have no competing interests.

\section{Author details}

${ }^{1}$ Hunan Provincial Key Laboratory for Biology and Control of Plant Diseases and Insect Pests, College of Plant Protection, Hunan Agricultural University, Changsha 410128, China. ${ }^{2}$ Hunan Provincial Engineering \& Technology Research Center for Biopesticide and Formulation Processing, Changsha 410128, China. ${ }^{3}$ Plant Protection and Inspection Station, Agriculture Bureau of Hanshou County, Hanshou 415900, China. ${ }^{4}$ Agriculture and Rural Department of Hunan Province, Plant Protection and Inspection Station, Changsha 410005, China.
Received: 29 September 2019 Accepted: 11 April 2020

Published online: 15 April 2020

\section{References}

1. Takeda M. Genetic basis of photoperiodic control of summer and winter diapause in geographic ecotypes of the rice stem maggot, Chlorops oryzae. Entomol Exp Appl. 1998;86(1):59-70.

2. Takeda M, Nagata T. Photoperiodic responses during larval development and diapause of two geographic ecotypes of the rice stem maggot, Chlorops oryzae. Entomol Exp Appl. 1992;63(3):273-81.

3. Takeda M. Effects of photoperiod and temperature on larval development and summer diapause in two geographic ecotypes of the rice stem maggot, Chlorops oryzae Matsumura (Diptera: chloropidae). Appl Entomol Zool. 1997;32(1):63-74.

4. Qiu L, Tao S, He H, Ding W, Li Y. Transcriptomics reveal the molecular underpinnings of chemosensory proteins in Chlorops oryzae. BMC Genom. 2018;19(1):890.

5. Chapuis MP, Lecoq M, Michalakis Y, Loiseau A, Sword GA, Piry S, Estoup A. Do outbreaks affect genetic population structure? A worldwide survey in Locusta migratoria, a pest plagued by microsatellite null alleles. Mol Ecol. 2008;17(16):3640-53.

6. Chapuis MP, Loiseau A, Michalakis Y, Lecoq M, Franc A, Estoup A. Outbreaks, gene flow and effective population size in the migratory locust, Locusta migratoria: a regional-scale comparative survey. Mol Ecol. 2009;18(5):792-800.

7. Assefa Y, Mitchell A, Conlong DE. Phylogeography of Eldana saccbarina Walker (Lepidoptera: Pyralidae). Ann Soc Entomol Fr. 2006;42(3-4):331-7.

8. Assefa Y, Conlong DE, Van Den Berg J, Martin LA. Ecological genetics and host range expansion by Busseola fusca (Lepidoptera: Noctuidae). Environ Entomol. 2015;44(4):1265-74.

9. Assefa Y, Goftishu M, Capdevielle-Dulac C, Ru BL. Clarifying the source of Conicofrontia sesamoides Hampson (Lepidoptera: Noctuidae) population in South African sugarcane using morphological identification and mitochondrial DNA analysis. Phytoparasitica. 2017;45(1):45-55.

10. Yi $C$, Zheng $C$, Zeng $L$, XuY. High genetic diversity in the offshore island populations of the tephritid fruit fly Bactrocera dorsalis. BMC Ecol. 2016;16(1):46.

11. Palraju M, Paulchamy R, Sundaram J. Population genetic structure and molecular diversity of Leucinodes orbonalis based on mitochondrial COl gene sequences. Mitochondrial DNA A DNA Mapp Seq Anal. 2018;29(8):1231-9.

12. Hemmati C, Moharramipour S, Seyahooei MA, Bagheri A, Mehrabadi M. Population genetic structure of Hishimonus phycitis (Hem.: Cicadellidae), vector of lime witches' broom phytoplasma. J Agric Sci Technol. 2018;20(5):999-1012.

13. Mutun $S$, Borst DW. Intraspecific mitochondrial DNA variation and historical biogeography of the eastern lubber grasshopper, Romalea microptera. Ann Entomol Soc Am. 2004;97(4):681-96.

14. Saccone C, De Giorgi C, Gissi C, Pesole G, Reyes A. Evolutionary genomics in Metazoa: the mitochondrial DNA as a model system. Gene. 1999;238(1):195-209.

15. Bucklin A, Wiebe PH, Smolenack SB, Copley NJ, Beaudet JG, Bonner KG, Färberlorda J, Pierson JJ. DNA barcodes for species identification of Euphausiids (Euphausiacea, Crustacea). J Plankt Res. 2007;29(6):483-93.

16. Smith MA, Fisher BL, Hebert PD. DNA barcoding for effective biodiversity assessment of a hyperdiverse arthropod group: the ants of Madagascar. Philos Trans R Soc Lond B Biol Sci. 2005;360(1462):1825-34.

17. Lakra WS, Goswami M, Gopalakrishnan A, Singh DP, Singh A, Nagpure NS. Genetic relatedness among fish species of Genus Channa using mitochondrial DNA genes. Biochem Syst Ecol. 2010;38(6):1212-9.

18. Hebert PD, Ratnasingham S, deWaard JR. Barcoding animal life: cytochrome c oxidase subunit 1 divergences among closely related species. Proc Biol Sci. 2003;270(Suppl 1):S96-9.

19. Prevost A, Wilkinson MJ. A new system of comparing PCR primers applied to ISSR fingerprinting of potato cultivars. Theor Appl Genet. 1999;98(1):107-12.

20. Nudin NFH, Ali AM, Ngah N, Mazlan NZ, Mat N, Ghani MNA, Alias N, Zakaria AJ, Jahan MS. ISSR marker-assisted genetic diversity analysis of 
Dioscorea hispida and selection of the best variety for sustainable production. C R Biol. 2017;340(8):359-66.

21. Sandra DJA, Ricardo FCM, Carlos SL, Cláudia FF, Vanderlei SS, Pascoal AM. Genetic structure of cassava populations (Manihot esculenta Crantz) from Angola assessed through (ISSR) markers. Afr J Biotechnol. 2019;18(7):144-54.

22. Salis C, Papadakis IE, Kintzios S, Hagidimitriou M. In vitro propagation and assessment of genetic relationships of citrus rootstocks using ISSR molecular markers. Not Bot Horti Agrobo. 2017;45(2):383-91.

23. Barrett RDH, Schluter $D$. Adaptation from standing genetic variation. Trends Ecol Evol. 2008;23(1):38-44.

24. Crawford KM, Whitney KD. Population genetic diversity influences colonization success. Mol Ecol. 2010;19:1253-63.

25. Raymond L, Plantegenes $M$, Vialatte A. Migration and dispersal may drive to high genetic variation and significant mixing: the case of two agriculturally important, continental hoverflies (Episyrphus balteatus and Sphaerophoria scripta). Mol Ecol. 2013;22:5329-39.

26. Xu Y, Mai JW, Yu BJ, Hu HX, Yuan L, Jashenko R, Ji R. Study on the genetic differentiation of geographic populations of Calliptamus italicus (Orthoptera: Acrididae) in Sino-Kazakh border areas based on mitochondrial COI and CO/l genes. J Econ Entomol. 2019;112(4):1912-9.

27. Millar Cl, Libby WJ, Falk DA, Holsinger KE. Strategies for conserving clinal, ecotypic, and disjunct population diversity in widespread species. Genet Conserv Rare Plants. 1991;149:170.

28. Garant D, Forde SE, Hendry AP. The multifarious effects of dispersal and gene flow on contemporary adaptation. Funct Ecol. 2007;21 (3):434-43.

29. Barton N, Partridge L. Limits to natural selection. BioEssays. 2000;22:1075-84.

30. Lenormand T. Gene flow and the limits to natural selection. Trends Ecol Evol. 2002;17:183-9.

31. Gandon S, Nuismer SL. Interactions between genetic drift, gene flow, and selection mosaics drive parasite local adaptation. Am Nat. 2009;173:212-24.

32. Ribeiro A, Llord P, Bowie RCK. A tight balance between natural selection and gene flow in a southern African arid-zone endemic bird. Evol. 2011;65:3499-514.

33. Lynch M, Conery J, Burger R. Mutation accumulation and the extinction of small population. Am Nat. 1995;146:485-518.
34. Crnokrak P, Roff DA. Inbreeding depression in the wild. Heredity. 1999;83:260-70.

35. Yang $Y Q$, Pu $\sqcup$, Wang $Q$, Wang Z, Pang ZP, Long YH. Population diversity of Odontotermes formosanus (Shiraki) (Termitidae, Macrotermitinae) from different geographic locations in Anhui province. China. Sociobiol. 2018;65(3):497-505.

36. Sun W, Dong H, Gao YB, Su QF, Qian HT, Bai HY, Zhang ZT, Cong B. Genetic variation and geographic differentiation among populations of the nonmigratory agricultural pest Oedaleus infernalis (Orthoptera: Acridoidea) in China. J Insect Sci. 2015;15:150.

37. Hall TA. BioEdit: a user-friendly biological sequence alignment editor and analysis program for Windows 95/98/NT. Nucleic Acid Symp Ser. 1999:41:95-8.

38. Tajima F. Statistical method for testing the neutral mutation hypothesis by DNA polymorphism. Genetics. 1989;123(3):585-95.

39. Fu YX. Statistical tests of neutrality of mutations against population growth, hitchhiking and background selection. Genetics. 1997;147(2):915-25.

40. Librado P, Rozas J. DnaSP v5: a software for comprehensive analysis of DNA polymorphism data. Bioinformatics. 2009;25(11):1451-2.

41. Polzin T, Daneshmand SV. On Steiner trees and minimum spanning trees in hypergraphs. Oper Res Lett. 2003;31:12-20.

42. Kumar S, Stecher G, Tamura K. MEGA7: molecular evolutionary genetics analysis version 7.0 for bigger datasets. Mol Biol Evol. 2016;33(7):1870-4.

43. Excoffier L, Lischer HE. Arlequin suite ver 3.5: a new series of programs to perform population genetics analyses under Linux and Windows. Mol Ecol Resour. 2010;10(3):564-7.

44. Yeh FC, Yang RC, Boyle T, Ye ZH, Mao JX. Popgene, the user friendly shareware for population genetic analysis. Edmonton: Molecular Biology and Biotechnology Center. University of Alberta; 1997.

45. Rohlf FJ. NTSYS-pc Numerical taxonomy and multivariate analysis system? Version 2.02e. Setauket: Exeter Software; 1997.

\section{Publisher's Note}

Springer Nature remains neutral with regard to jurisdictional claims in published maps and institutional affiliations.
Ready to submit your research? Choose BMC and benefit from:

- fast, convenient online submission

- thorough peer review by experienced researchers in your field

- rapid publication on acceptance

- support for research data, including large and complex data types

- gold Open Access which fosters wider collaboration and increased citations

- maximum visibility for your research: over $100 \mathrm{M}$ website views per year

At BMC, research is always in progress.

Learn more biomedcentral.com/submissions 